\title{
Islamic State of Afghanistan: First Review Under the Staff-Monitored Program
}

This paper on the first review under the staff-monitored program for the Islamic State of Afghanistan was prepared by a staff team of the International Monetary Fund as background documentation for the periodic consultation with the member country. It is based on the information available at the time it was completed on November 8, 2004. The views expressed in this document are those of the staff team and do not necessarily reflect the views of the government of the Islamic State of Afghanistan or the Executive Board of the IMF.

The policy of publication of staff reports and other documents by the IMF allows for the deletion of market-sensitive information.

To assist the IMF in evaluating the publication policy, reader comments are invited and may be sent by e-mail to publicationpolicy@imf.org.

Copies of this report are available to the public from

International Monetary Fund • Publication Services

700 19th Street, N.W. • Washington, D.C. 20431

Telephone: (202) $6237430 \bullet$ Telefax: (202) 6237201

E-mail: publications@imf.org • Internet: http://www.imf.org

Price: $\$ 15.00$ a copy

\section{International Monetary Fund Washington, D.C.}



INTERNATIONAL MONETARY FUND

ISLAMIC STATE OF AFGHANISTAN

First Review Under the Staff-Monitored Program

Prepared by the Middle East and Central Asia

and Policy Development and Review Departments

(In consultation with other departments)

Approved by Saleh M. Nsouli and Matthew Fisher

November 8, 2004

- A 12-month staff monitored program (SMP), which covers the fiscal year 2004/05

(March 20, 2004-March 20, 2005), is being implemented by the authorities. The SMP aims at maintaining financial stability while building the institutional capacity toward a Fund-supported arrangement under the Poverty Reduction and Growth Facility (PRGF).

- $\quad$ Discussions for the first review under the SMP were held in Kabul during July 11-25, 2004. The mission met with Vice President Arsala, Minister of Finance Ghani, Minister of Foreign Affairs Abdullah, Da Afghanistan Bank Governor Ahady, other senior officials, as well as representatives of the diplomatic community, NGOs, business community, and international organizations.

Mr. Farhadi (advisor to Mr. Mirakhor) participated in some of the policy discussions.

- $\quad$ The staff members consisted of Messrs. Symansky (head), Bessaha, Martin (all MCD), Schneider (PDR), and Thomas (FAD). The mission was assisted by the resident representative, Mr. de Schaetzen.

- The security situation is volatile and could deteriorate in the run-up to the presidential elections, scheduled for October 9, 2004. The government does not exercise full control over all provinces, and the United Nations continues to rate Afghanistan at Security Phase III.

- The Afghan authorities published the concluding statement of the first quarterly review and have agreed to publish the staff report and the updated Memorandum of Economic and Financial Policies (MEFP) and Letter of Intent (LOI) after their distribution to the Executive Board. 


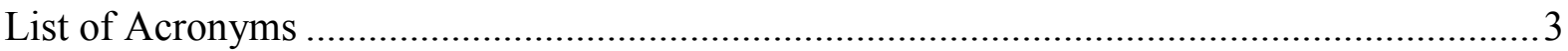

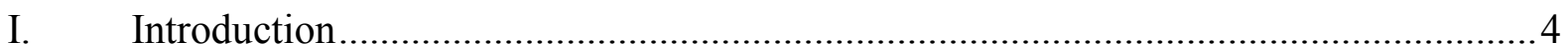

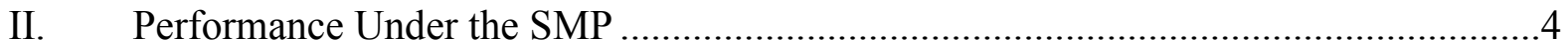

III. Recent Economic Developments ....................................................................... 5

IV. Macroeconomic Outlook and Policy Framework .............................................. 6

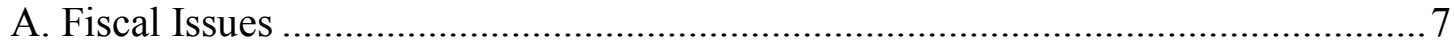

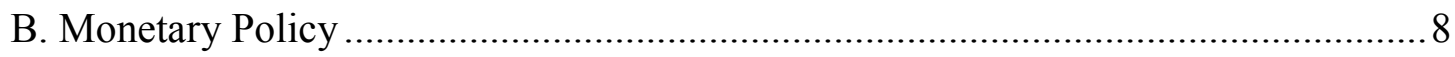

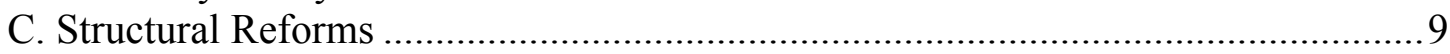

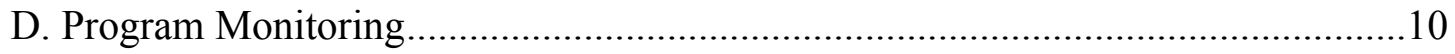

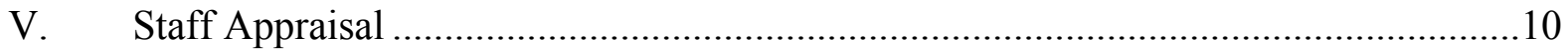

Figures

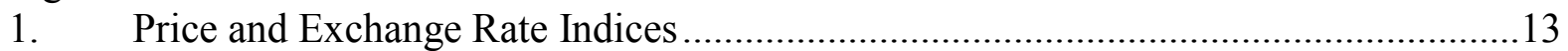

Tables

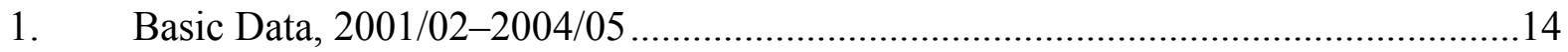

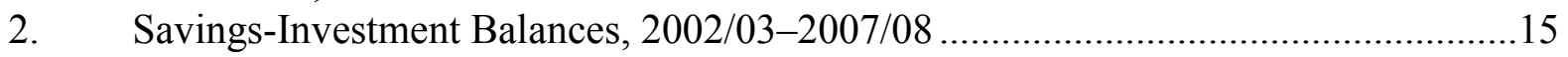

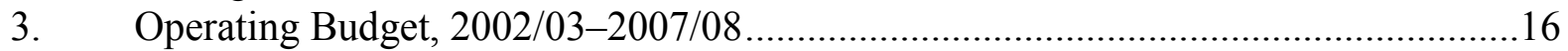

4. Monetary Program (Da Afghanistan Bank), 2003/04-2004/05 ..............................17

5. Balance of Payments, 2001/02-2007/08 ................................................................. 18

Appendices

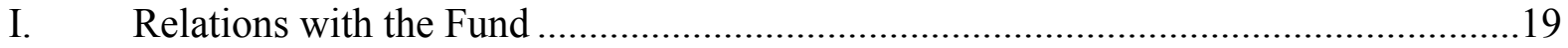

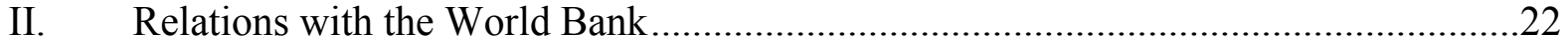

Attachments

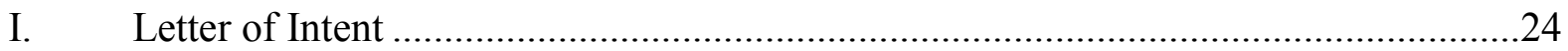

II. Update to the Memorandum of Economic and Financial Policies ............................26

III. Amendments to the Technical Memorandum of Understanding ..............................38 


\section{List of Acronyms}

$\begin{array}{ll}\text { AML/CFT } & \text { Anti-Money Laundering and Combating the Financing of Terrorism } \\ \text { ARTF } & \text { Afghanistan Reconstruction Trust Fund } \\ \text { CIRR } & \text { Commercial Interest Reference Rates } \\ \text { CPI } & \text { Consumer Price Index } \\ \text { DAB } & \text { Da Afghanistan Bank } \\ \text { EPB } & \text { Export Promotion Bank } \\ \text { IFS } & \text { International Financial Statistics } \\ \text { LOI } & \text { Letter of Intent } \\ \text { MEFP } & \text { Memorandum of Economic and Financial Policies } \\ \text { MoF } & \text { Ministry of Finance } \\ \text { NPPs } & \text { National Priority Programs } \\ \text { OECD } & \text { Organization for Economic Cooperation and Development } \\ \text { PRGF } & \text { Poverty Reduction and Growth Facility } \\ \text { SMP } & \text { Staff-Monitored Program } \\ \text { SOEs } & \text { State-Owned Enterprises } \\ \text { TC } & \text { Inter-Ministerial Technical Committee } \\ \text { TMU } & \text { Technical Memorandum of Understanding } \\ \text { TSA } & \text { Treasury Single Account } \\ \text { TSS } & \text { Transitional Support Strategy } \\ \text { UNODC } & \text { United Nations Office on Drugs and Crimes }\end{array}$




\section{INTRODUCTION}

1. On November 21, 2003, the Executive Board concluded the 2003 Article IV consultation with the Islamic State of Afghanistan - the first such consultation since 1991. Executive Directors noted that prudent macroeconomic management over the past 18 months had, together with sizable aid and the end of the drought, provided an environment conducive to the resumption of economic growth. They also underscored the need for the international community to remain engaged and for the donors to continue to provide substantial assistance. Directors noted that fiscal discipline required further donor support and revenue-raising measures to ensure the independence of the operating budget in due course. They saw merit in a "lightly managed" float for a country that remains vulnerable to shocks and is undergoing structural changes and reconstruction. Directors urged the authorities to undertake, with technical assistance from the Fund and other donors, improvements in the statistical database. They were concerned about the risks posed by the opium economy and urged the authorities to intensify eradication, while offering alternative livelihoods. Directors supported Afghanistan's intentions to undertake a SMP and viewed it as an important step for the preparation for a PRGF arrangement.

2. During 2001-03, the government of Afghanistan focused its efforts on crisis management, and establishing or rebuilding the basic institutions of government and essential public services. The Fund's role during this period centered around provision of technical assistance, facilitated by a resident representative. During the 2003 IMF-World Bank Annual Meetings in Dubai, the authorities expressed interest in closer Fund involvement. Given the government's limited administrative capacity and the absence of a pressing balance of payments need, a SMP was seen as the appropriate first step toward a more formal arrangement. On March 20, 2004, the authorities began implementation of a 12-month SMP, designed at maintaining macroeconomic and financial stability, achieving key structural reforms, building statistical capacity, and better coordinating technical assistance.

3. There have been several encouraging developments since the start of the program. A high-level donors' conference held in Berlin during March 31-April 1, 2004 resulted in new pledges seen as adequate to meet Afghanistan's development needs over the next few years. The government is moving ahead with political reforms, and presidential elections are slated for October 9, 2004. While the security situation remains volatile, especially in the run-up to the elections, the government has been successful in implementing a wide range of reforms, and this is expected to continue through the coming months.

\section{Performance Under The SMP}

4. A staff team visited Kabul during the period July 11-25, 2004 to review performance under the SMP for the first quarter of the program (April-June 2004). Performance during this period has been broadly in line with the commitments made under the program. The authorities have met all of the indicative quantitative targets set out 
under the SMP and all the structural benchmarks, except the benchmark on licensing of commercial banks, which was only partly met due to the opposition of the shareholders of Export Promotion Bank (EPB) to its merger with three other state-owned banks. As a result, EPB had to resubmit an application for relicensing. A final decision regarding EPB's application is now an end-September 2004 structural benchmark. The mission also agreed with the authorities on a revised macroeconomic framework and structural benchmarks for the remainder of the program.

5. The staff view the authorities' performance in the first quarter as a notable achievement, but are cognizant that meeting the objectives established for the remainder of the program will take a continued major effort. The results achieved so far were due largely to the determined efforts of the Ministry of Finance (MoF) and the central bank to deliver on an ambitious reform agenda. Meeting the quantitative targets and structural benchmarks set out for the remainder of the program, however, will require support and cooperation from the government as a whole. In particular, this requires that the recently established Inter-ministerial Committee to monitor the SMP play a more active role in the months ahead. Recent Cabinet approval of the update to the MEFP is indicative of the broad-based ownership of the program.

\section{RECENT ECONOMIC DEVELOPMENTS}

6. There have been significant revisions to key economic indicators, including the downward revision in GDP growth for 2003/04, from 23 percent to 16 percent, largely reflecting lower-than-anticipated output in the agricultural sector (Tables 1 and 2). Meanwhile, inflation and exchange rate developments are providing conflicting signals regarding monetary policy. On one hand, inflation (currently measured only in Kabul) has been somewhat higher than expected as prices rose by 6.9 percent during the first quarter of 2004/05 (Figure 1). This quarterly performance mainly reflected seasonal and tax-related factors, as well as the impact of the higher spending by the donor community on rents and the prices of other nontraded goods. On the other hand, the exchange rate has been appreciating.

\section{Currency in circulation during the first quarter of 2004/05 was lower than} programmed although the rate of growth accelerated toward the end of the quarter, while the accumulation of international reserves exceeded its target (Table 4).

The Afghani has remained strong through the first quarter of 2004/05, which appears to reflect an increased willingness by the population, particularly in rural areas, to accept the new currency as a medium of exchange and a store of value. The strength of the Afghani was also supported by prudent macroeconomic policies including strict application of a "no-overdraft rule" by the MoF and adherence by the central bank to the SMP monetary growth target.

8. Opium production continues to play an important role in the economy and has been on the rise since end-2001. Production in 2003 is estimated by the United Nations Office on Drugs and Crimes (UNODC) to have reached 3,600 tons, a 6 percent rise over 2002. 
Exports of opium and opium derivatives are estimated to have generated receipts of about $\$ 2.5$ billion and \$2.3 billion in 2002 and 2003, respectively. Data on the 2004 crop will be released in late October by the UNODC. Preliminary information indicates that after reaching near record levels in 2003, farmgate prices have declined. This appears to be attributable to a large increase in supply and some success in the interdiction policy (which reduces demand from the farmers). While the government, together with the donors, have embarked on a three-pronged strategy of eradication, interdiction, and developing alternative livelihoods, their efforts have had limited success to date.

9. Fiscal revenue for the first quarter of 2004/05 is estimated to have reached Af 2.64 billion, slightly exceeding the SMP target level of Af 2.59 billion (Table 3). Similar to the pattern observed in 2003/04, the government's operating expenditures during the first quarter (Af 4.8 billion) were well below what might have been expected given a budgeted amount of Af 30.3 billion (10.5 percent of GDP) for all of 2004/05. The slow pace of spending during the first quarter was largely attributed to problems in communicating budget allotments and the employee register to line ministries and the provincial government units (moustoufiats), ongoing procurement constraints, and weak financial management capacity. Given the high level of demand for improved security, reconstruction, and poverty reduction, the mission emphasized the need for the government to try and meet its spending objectives in these priority areas while ensuring that appropriate expenditure controls are in place to safeguard and account for these resources.

10. Reliable balance of payments data are not yet available, although efforts to build statistical capacity in this area are under way. Best estimates, however, indicate that the external current account (excluding grants) deteriorated significantly in 2003/04, due largely to a surge in imports associated with reconstruction and rising consumer demand (Table 5).

\section{Macroeconomic Outlook ANd Policy Framework}

11. The discussions with the authorities focused on maintaining macroeconomic stability in a period of massive economic change, along with capacity building and the structural reforms necessary to support successful performance under the SMP. While staff remain concerned about potential downside risks to the macroeconomic outlook because of continued insecurity in a number of provinces and the re-emergence of drought, these appear balanced by the continuous delivery of external assistance following the Berlin donors' conference, growing confidence in the Afghani, and the expected coming onstream of several projects in the agricultural and manufacturing sectors. Also encouraging has been the pace of structural and policy reform over the last two years. Critical measures, such as licensing of commercial banks, passage of key customs and revenue reforms, improved financial and fiscal reporting, adoption of a comprehensive current and development budget, improved public expenditure management, and some initial steps in dealing with civil service pay reform and state-owned enterprises (SOEs), are laying a strong basis for future performance. 
12. The significant revision of key economic indicators for 2003/04 warranted a revision of the medium-term macroeconomic framework. The recent pickup in inflation is a concern and will be monitored closely. In light of the first quarter outturn and based on current trends, the inflation projection has now been adjusted to 10 percent, compared with 5 percent under the original framework. GDP growth is now projected at 16 percent in $\mathbf{2 0 0 4 / 0 5}$, compared with 15 percent under the original framework, on the assumptions of better rainfalls and improved agricultural infrastructure. The construction sector is also expected to perform strongly. This, together with a stable exchange rate, is expected to lead to a rise in per capita income to $\$ 246$, up from $\$ 199$ in $2003 / 04$.

13. Against this background, the government and the staff reached understandings on a revised macroeconomic framework for $2004 / 05$ and on a set of structural benchmarks for end-December 2004 and end-March 2005 that continue to support macroeconomic stability and the government's structural reforms. The staff view these targets and benchmarks as ambitious but achievable. In terms of implementation, much will depend on intra-governmental cooperation and mustering broad political support for the program.

\section{A. Fiscal Issues}

14. Meeting the revenue targets set out under the program will require concerted efforts by the authorities to address deficiencies in collection and transfer. Fiscal revenue (excluding grants) during the first quarter of FY 2004/05 was significantly higher than during the same period last year, but only slightly above the target set out in the SMP, which is consistent with an annual projection that is far less ambitious than the budget forecast. Reaching the budgeted revenue target for the year will therefore be a challenge. Consequently, the government reiterated its commitment to fully implement a wide range of planned customs and tax reforms, step up collection efforts, particularly in the provinces for customs, and eliminate tax holidays and concession agreements. The mission warned that success will require an intense cooperation among ministries and the provincial authorities. The mission also urged the authorities to address the legal and institutional bottlenecks and to identify the policy issues that have delayed a considerable amount of economic legislation. The current system is hampered by a lack of clarity regarding the exactitude of the legal process, including the drafting and publication of laws in the official gazette.

\section{Expenditure management must be improved if development objectives are to} be met. The mission welcomed the adoption in June 2004 of a 'core budget,' which consolidated the operating budget with development expenditures that are financed by donors but reported through government systems. This should significantly enhance fiscal coordination and transparency. Continued adherence to the "no-overdraft rule" will ensure that fiscal policy is designed to avoid inflationary financing. At the same time, actions to fully utilize available grants and concessional financing should substantially increase the resources available for priority spending. In spite of the slow pace of operating budget spending during the first quarter of the year, the staff strongly support the authorities' efforts to enforce appropriate expenditure controls to ensure accountability. There are 
reasons to believe that there will be a significant pickup in spending during the remainder of the year as public expenditure management systems and capacity improve. The Afghan Reconstruction Trust Fund (ARTF) has only been able to reimburse a small percentage of the nonwage expenses submitted to them because of inadequate documentation. Improvement will require some fundamental changes in the financial management practices, including additional training, by the line ministries and in the provinces, and efforts are already under way to address this problem. The government is also encouraged to continue its efforts to work more closely with donors to enhance the pace and effectiveness of development expenditures.

\section{B. Monetary Policy}

16. The built-in flexibility mechanism in the monetary program developed with Fund staff in March 2004 will help Da Afghanistan Bank (DAB) to continue to effectively implement a monetary policy stance aimed at lowering inflation, while guarding against currency instability. ${ }^{1}$ In line with the SMP, the authorities continue to target currency in circulation and allow for some movement in the exchange rate. As designed, the monetary program allows the central bank some room to accommodate apparent shifts in money demand. Indicative targets for growth in currency in circulation will thus remain unchanged for now. Consistent with the approach to the target for currency in circulation, and given that a substantial portion of the buildup in international reserves stemmed from accumulation of government deposits, the indicative target for gross international reserves of DAB will also remain unchanged. An increase in the reserve target may be considered at the time of the second review, however, if current trends continue.

17. Should the available flexibility in the monetary program prove insufficient, the staff stands ready to discuss with the authorities the need for an adjustment of the monetary policy framework. ${ }^{2}$ Close attention to available macroeconomic and financial indicators will be critical in this regard. However, as the current consumer price index (CPI)—which is limited to Kabul - is still a weak indicator for inflation across the country, relatively more attention will be devoted to exchange rate developments. Further attention must also be devoted to better understanding the factors driving monetary conditions in Afghanistan. Monthly cash flow projections from the $\mathrm{MoF}$, for example, will be one crucial element in this exercise.

\footnotetext{
${ }^{1}$ While the program target is set at 26 percent, the program allows for growth of currency up to 31 percent. However, if currency growth appears to jeopardize the quarterly target consistent with the 26 percent growth rate, the government is expected to discuss developments with the Fund, in order to assess the implications for price and exchange rate stability. Currency outturns consistent with rates of growth over 31 percent trigger a formal consultation with the Fund (see paragraphs 26-29 of MEFP of March 25; IMF Country Report No. 04/110, March 26, 2004).

${ }^{2}$ After the July mission, and in consultation with Fund staff, DAB exceeded the target for currency in circulation to limit the appreciation of the Afghani.
} 


\section{Structural Reforms}

18. The authorities have taken welcome steps to begin rationalizing the public enterprise sector and create an environment conducive to private sector-led growth. The authorities are currently conducting an assessment of the financial situation of SOEs, which will help them decide which enterprises are to be liquidated, which are to be privatized, and which are to remain in the government's portfolio. An action plan is also being prepared to address critical deficiencies in the investment climate. Key measures are to center on reform of the commercial code, property rights, and bankruptcy legislation.

\section{The authorities intend to continue their efforts to create a sound financial} system. In this context, the central bank will work toward improving the payments system, which is an essential element in extending the delivery of government services outside of Kabul. The central bank will also proceed with bank licensing and strengthen its supervision. In addition, the central bank is working toward having a proper balance sheet by eliminating its commercial activities and transferring nonmonetary assets to the MoF. Finally, an auction process for a short-term capital note will be introduced, which the staff see as the first step in establishing a benchmark interest rate and domestic credit market.

20. The mission recognizes that, since its inception, the Inter-Ministerial Technical Committee (TC) has been instrumental in effectively monitoring the implementation of the SMP and in providing core data to the Fund. Looking ahead, the staff encouraged the $\mathrm{TC}$ to focus its efforts on the timely execution of the SMP, intensifying the dialogue between government agencies, and setting the standards for better economic management.

21. The staff continue to see capacity building — in a broad range of areas - as the foundation of sustainable macroeconomic management and perhaps the single most important precursor to a formal Fund arrangement. This will require improving policy formulation capacity, strengthening economic management, and reinforcing the legal institutional framework. ${ }^{3}$ The establishment of the Middle Eastern Technical Assistance Center in Beirut will provide a good opportunity for the authorities to seek more technical assistance support from the Fund and improve the coordination of technical assistance by the donor community. Building Afghanistan's statistical capacity will also be key. Expansion of the CPI to five additional cities will provide a sounder basis for the evaluation of monetary policy, while regular publication of quarterly fiscal data will aid in putting macro-fiscal coordination on a sound footing. Implementing a plan to record duty-exempt imports should aid in evaluating the impact of donor spending on the external accounts. Finally, work on debt reconciliation and the development of a coherent government-backed strategy on debt management must also continue to ensure medium- and long-term external sustainability.

\footnotetext{
${ }^{3}$ However, the departure in recent months, at the end of their contracts, of several international experts holding key economic and financial positions has raised some concerns about the capacity building process.
} 


\section{Program Monitoring}

22. In accordance with the program objectives, understandings were reached on a set of structural benchmarks for end-December 2004 and end-March 2005 (LOI; paragraph 26 of MEFP; and Appendix I, Tables 1-2). The second and third reviews under the SMP are tentatively scheduled to be completed by end-October 2004, and end-January 2005, respectively, although dates may shift depending on security and mission travel concerns.

During the third review, the mission will discuss with the authorities the appropriate next steps in terms of Fund involvement. The authorities have indicated that a formal arrangement supported by the PRGF is their eventual goal. However, during the political transition leading to the election of a parliament in April 2005, they favor a successor SMP. These issues will be discussed with the newly elected government, once elections have been completed and Cabinet ministers have taken up their portfolios. Should a balance of payments need arise in the interim, Emergency Post Conflict Assistance could be considered.

\section{Staff Appraisal}

23. Despite a difficult security environment, the government has demonstrated a high level of performance during the first three months of the SMP. It is clear, however, that the remaining three quarters will be no less difficult than the first. The authorities should demonstrate diligence to ensure that key program targets and benchmarks are met.

24. At the same time, the paucity of reliable economic data and the rapidly changing economic environment imply that flexibility and a willingness to reevaluate previous assumptions will continue to be necessary. Continued close consultation with Fund staff will be the critical element in this regard.

\section{The staff are encouraged that the authorities were able to meet the revenue} target specified for the first quarter under the SMP, but note that the outturn was well below the more ambitious target set under the budget. ${ }^{4}$ The government's ability to meet future revenue targets will depend critically on the improvement of the security situation but also on implementation of customs and tax reforms, and concrete progress in improving collection efforts. Full collection of customs duties in the provinces is a clear priority, as is the elimination of tax holidays and concession agreements. While legislation has been enacted to control the loss of revenue from these agreements, the staff are concerned that many concession agreements remain in force and have significant implications for revenue collection.

\footnotetext{
${ }^{4}$ The budget adopted by the government projects domestic revenue of Af 15.4 billion ( $\$ 308.6$ million) in FY 2004/05, compared to Fund staff projections of Af 12.8 billion ( $\$ 256$ million), which represents a 25 percent increase over the previous fiscal year. Given the authorities' continued commitment to the "no-overdraft rule," and in the absence of additional external financing, any shortfall in the budgeted amount of revenue would necessitate either an offsetting reduction in operating expenditure or the switching of financing that is currently earmarked for development expenditures to fund the operating budget.
} 
26. Expenditure management is improving, but much remains to be done. The staff are encouraged by the steps taken thus far, and view the development of a "core budget" as evidence of the authorities' commitment and rapidly growing capacity in this area. The planned adoption of a financial management law, a key element of the public expenditure management reform process, will be another step in strengthening the legal framework for fiscal management. Nonetheless, the low expenditure figures in the first quarter and the failure to satisfy the accountability standards of the ARTF are evidence that there are still fundamental problems. Full utilization of donor grants and other resources for development projects, along with timely payments under the current budget, will be a key test for the government.

\section{Staff recognize that the conduct of monetary policy is complicated at this}

juncture by the high degree of uncertainty in money demand, major structural changes in the economy, the relatively poor quality and limited coverage of price data, external factors, such as oil price increases and price pressure induced by expatriate spending, and the limited monetary instruments available to DAB. Furthermore, the exchange rate and prices are currently providing conflicting signals. The staff share the authorities' concern that an excessive appreciation of the Afghani may hinder the development of the export sector. However, given the rise in consumer price inflation, the mission took the view that there was no need to loosen the monetary target or change the framework at this time. Rather, the authorities should use the additional room for monetary expansion allowed under the program. However, if the exchange rate continues to appreciate and upward price pressure abates, the staff could support a reformulation of the SMP indicative target for currency in circulation for end-December 2004 and end-March 2005. The more difficult policy problem will be if the current trends continue. The staff see as important that adjustment be spread across key variables. In this regard, relatively more weight will be paid to the exchange rate (one of the few variables for which timely and accurate data is available), but consumer prices - particularly as the CPI is extended outside of Kabul to five additional cities — will also be closely monitored.

28. The financial sector is gradually developing, and staff welcome the DAB's timely and effective action in completing the relicensing process for the state banks, as well as granting licenses to new private commercial banks, which have a large degree of foreign investment and management. While supporting the authorities' efforts to create a "clean" $\mathrm{DAB}$ balance sheet, they need to ensure adequate capitalization. The introduction of a short-term capital note by DAB is another welcome development, as it sets the stage for development of a domestic credit market - a fundamental element in facilitating bank intermediation and investment.

29. Structural reform and capacity building remain at the heart of the SMP, and staff welcome the authorities' desire to undertake an ambitious agenda in this regard. While the list of structural benchmarks included in the SMP is long, it should be noted that several of the new benchmarks came at the request of the government. Overall, staff view these benchmarks as achievable, practical, and essential to building fundamental administrative and statistical capacity, and facilitating private sector growth. 
30. Overall, the government's performance under the SMP during the first three months has been strong. In the months ahead, the main risks facing the SMP relate to the security situation and the uncertainty surrounding the political process. Notwithstanding these concerns, staff consider the authorities' track record and level of commitment as encouraging. In this regard, although the indicative targets and structural benchmarks for the remainder of the program are ambitious, they are achievable. 


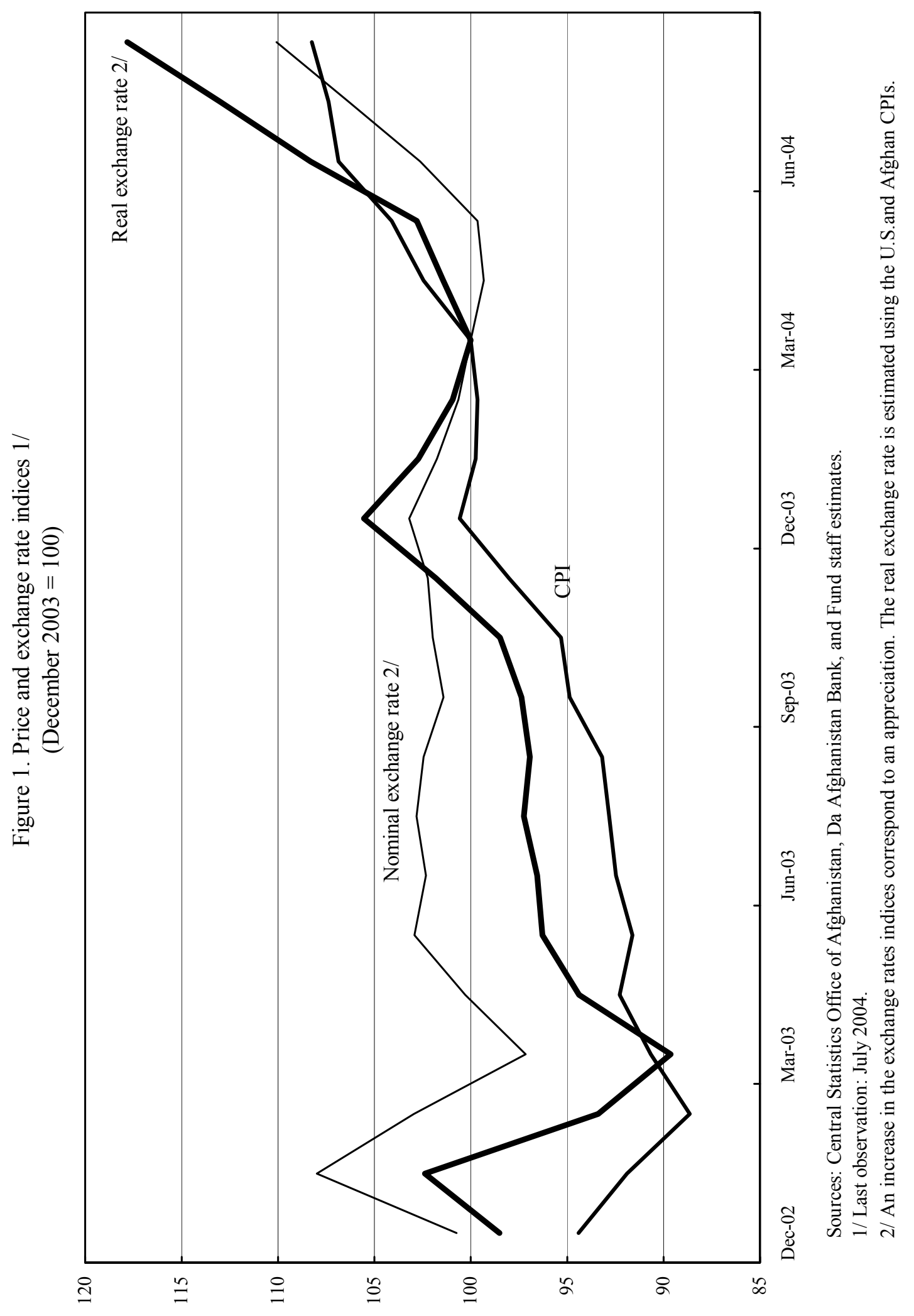


Table 1. Islamic State of Afghanistan: Basic Data, 2001/02-2004/05 1/

\begin{tabular}{|c|c|c|c|c|c|c|}
\hline & \multirow{2}{*}{$\begin{array}{r}\text { 2001/02 } \\
\text { Est. }\end{array}$} & \multirow{2}{*}{$\begin{array}{r}\text { 2002/03 } \\
\text { Est. }\end{array}$} & \multicolumn{2}{|c|}{$2003 / 04$} & \multicolumn{2}{|c|}{$2004 / 05$} \\
\hline & & & $\begin{array}{r}\text { Init. 2/ } \\
\text { Est. }\end{array}$ & $\begin{array}{r}\text { Revised } \\
\text { Est. }\end{array}$ & $\begin{array}{r}\text { Init. 2/ } \\
\text { Proj. }\end{array}$ & $\begin{array}{r}\text { Revised } \\
\text { Proj. }\end{array}$ \\
\hline \multicolumn{7}{|c|}{ I. Economic and Financial Indicators } \\
\hline \multicolumn{7}{|l|}{ Production } \\
\hline GDP (in millions of U. S. dollars, excluding opium production) & 2,463 & 4,048 & 4,704 & 4,585 & 5,577 & 5,802 \\
\hline GDP (in millions of new Afghani) & 133,987 & 181,350 & 230,962 & 225,108 & 277,950 & 289,180 \\
\hline Real GDP growth rate (in percent) & $\ldots$ & 29 & 23 & 16 & 15 & 16 \\
\hline GDP per capita (in U. S. dollars) & 123 & 181 & 207 & 199 & 236 & 246 \\
\hline Opium production (metric tons) & 185 & 3,400 & 3,600 & $\ldots$ & 3,600 & $\ldots$ \\
\hline Opium value (in millions of U. S. dollars) & $\ldots$ & 2,540 & 2,320 & $\ldots$ & 2,320 & $\ldots$ \\
\hline \multicolumn{7}{|l|}{ Consumer prices } \\
\hline CPI (Kabul, percentage change year-on-year) & -43.4 & 52.3 & 9.0 & 10.3 & 5.0 & 10.2 \\
\hline CPI (Kabul, percentage change on average) & $\ldots$ & 5.2 & 24.0 & 24.2 & 5.0 & 12.3 \\
\hline & \multicolumn{6}{|c|}{ (In millions of U. S. dollars, unless specified otherwise) } \\
\hline \multicolumn{7}{|l|}{ General government recurrent budget } \\
\hline Revenues & $\ldots$ & 132 & 190 & 207 & 256 & 256 \\
\hline Expenditures & $\ldots$ & 349 & 430 & 451 & 609 & 609 \\
\hline Donor grants and loans & $\ldots$ & 209 & 247 & 205 & 300 & 352 \\
\hline Revenues (in percent of non-opium GDP) & $\ldots$ & 3.2 & 4.0 & 4.5 & 4.6 & 4.4 \\
\hline Expenditures (in percent of non-opium GDP) & $\ldots$ & 8.6 & 9.1 & 9.8 & 10.9 & 10.5 \\
\hline \multicolumn{7}{|l|}{ Monetary indicators } \\
\hline Domestic currency in circulation (annual percentage change) & $\ldots$ & 20.1 & 35.5 & 40.9 & 26.4 & 25.7 \\
\hline Gross foreign exchange reserves (in millions of U. S. dollars) & $\ldots$ & 426.1 & 772.6 & 815.5 & 883.6 & 977.0 \\
\hline & \multicolumn{6}{|c|}{ (In millions of U. S. dollars, unless specified otherwise) } \\
\hline \multicolumn{7}{|l|}{ External sector } \\
\hline Exports of goods (including reexports) & 708.9 & $1,248.3$ & $2,778.6$ & $1,700.8$ & $2,362.2$ & $1,822.5$ \\
\hline Imports of goods & $1,645.0$ & $2,407.6$ & $4,388.0$ & $3,758.9$ & $4,682.8$ & $4,134.1$ \\
\hline Current account deficit (excluding grants) & $\ldots$ & $-1,305.5$ & $-1,818.2$ & $-2,578.2$ & $-2,770.6$ & $-2,838.7$ \\
\hline Current account deficit (including grants, in percent of GDP) & $\ldots$ & -2.1 & -3.4 & -0.9 & -4.8 & -1.6 \\
\hline Afghani/U. S. dollar (average during fiscal year) & 54.4 & 44.8 & 49.0 & 49.0 & $\ldots$ & $\ldots$ \\
\hline \multirow[t]{2}{*}{ Afghani/U. S. dollar (end-fiscal year) } & 31.0 & 52.6 & 50.3 & 50.3 & $\ldots$ & $\ldots$ \\
\hline & \multicolumn{6}{|c|}{ (In percent of GDP) } \\
\hline \multicolumn{7}{|l|}{ Investment and savings } \\
\hline Gross investment & $\ldots$ & 19.8 & 34.0 & 37.6 & 43.3 & 43.2 \\
\hline Domestic savings & $\ldots$ & -15.2 & -4.6 & -18.6 & -6.4 & -5.7 \\
\hline \multicolumn{7}{|c|}{ II. Social and Demographic Indicators } \\
\hline Area & \multicolumn{6}{|c|}{652,000 square kilometers } \\
\hline Population $(2002 / 03)$ & \multicolumn{6}{|c|}{21.8 million } \\
\hline Life expectancy at birth (2001) & \multicolumn{6}{|l|}{42.8 years } \\
\hline Infant mortality per 1,000 live births (2001) & \multicolumn{6}{|l|}{165} \\
\hline Under-five mortality per 1,000 live births (2001) & \multicolumn{6}{|l|}{257} \\
\hline
\end{tabular}

Sources: Afghan authorities; and Fund staff estimates and projections.

1/ The fiscal year 1383 runs from March 20, 2004 until March 20, 2005.

2/ Staff-monitored program dated March 26, 2004 (IMF Country Report No. 04/110). 


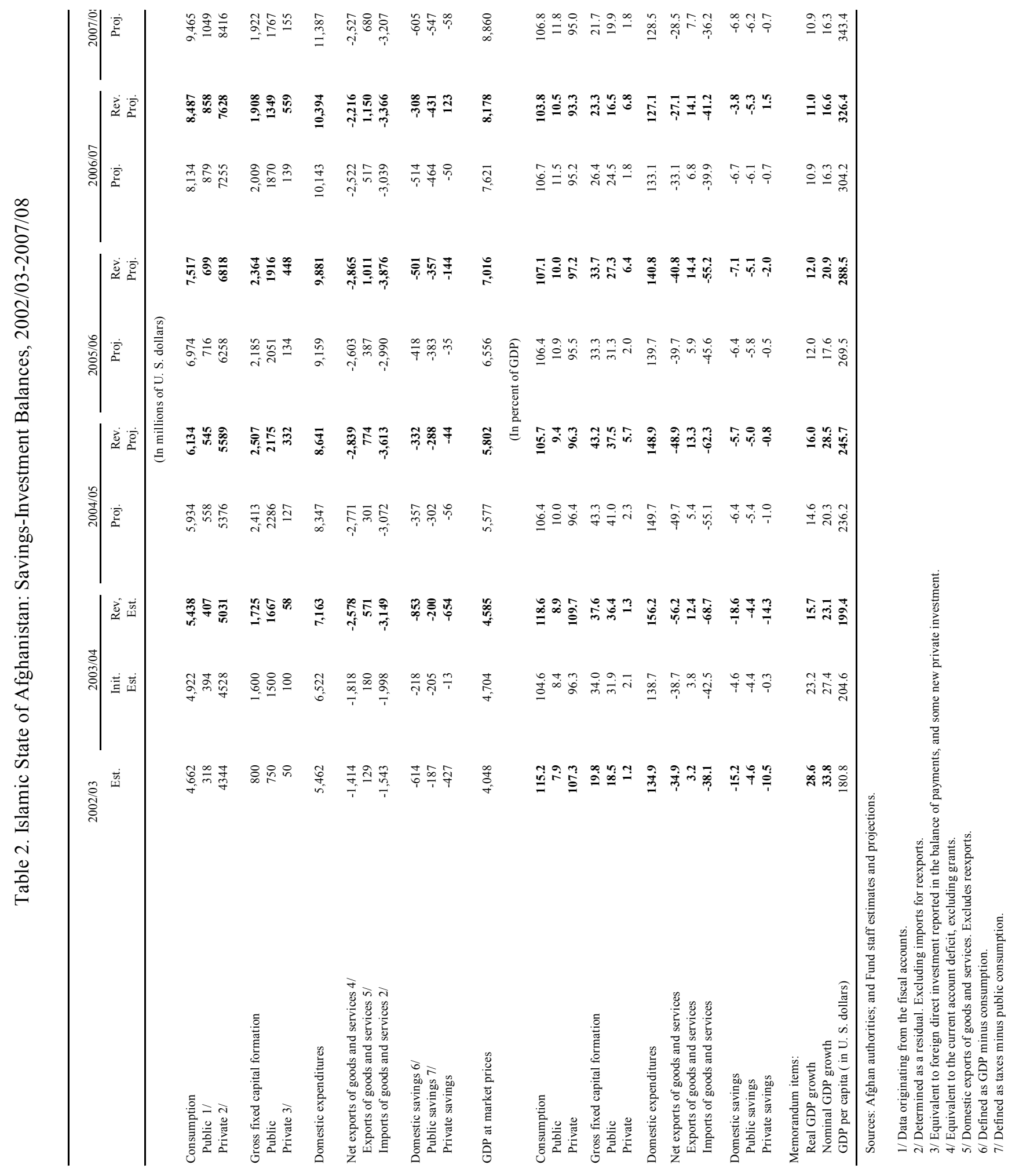




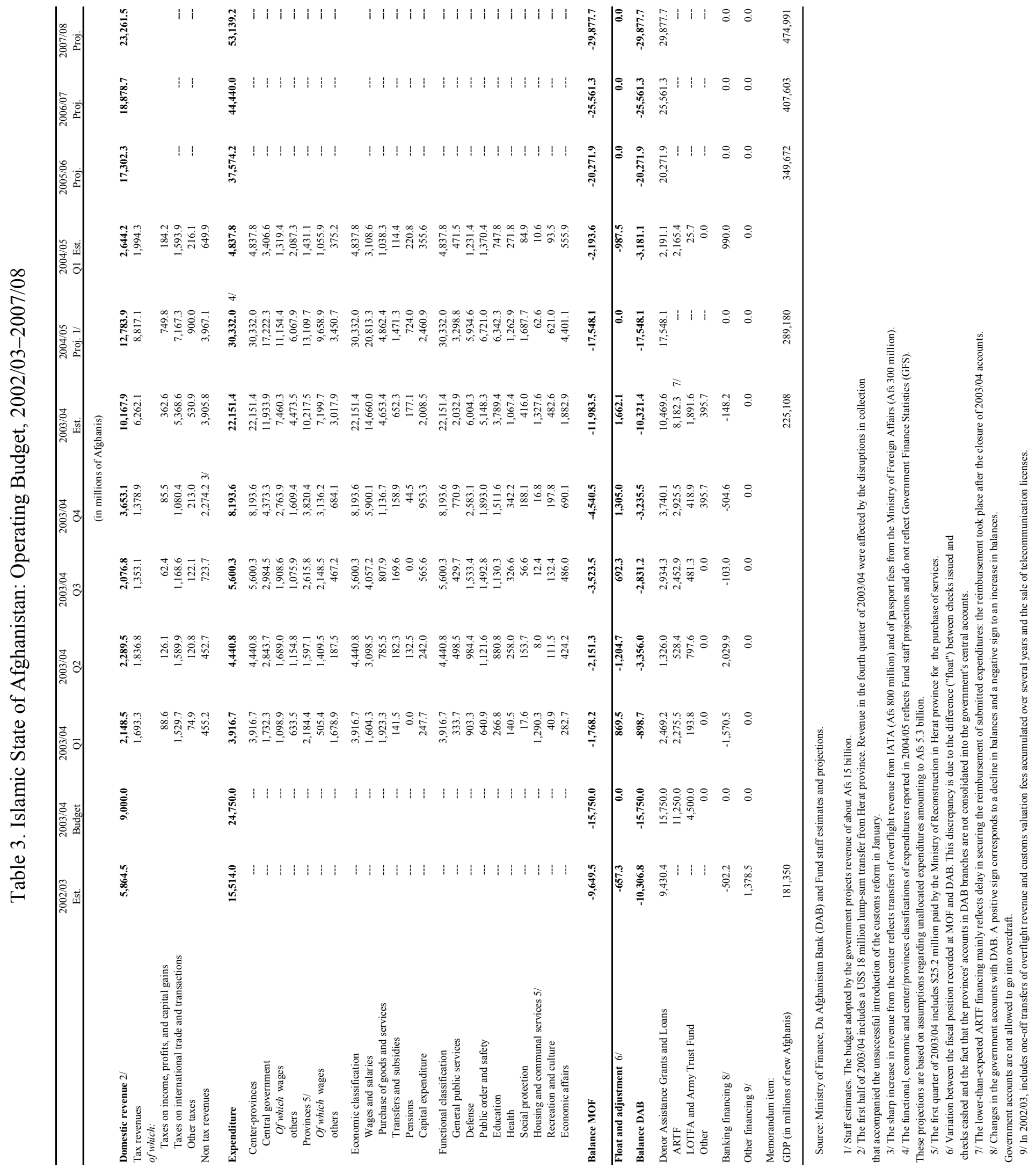




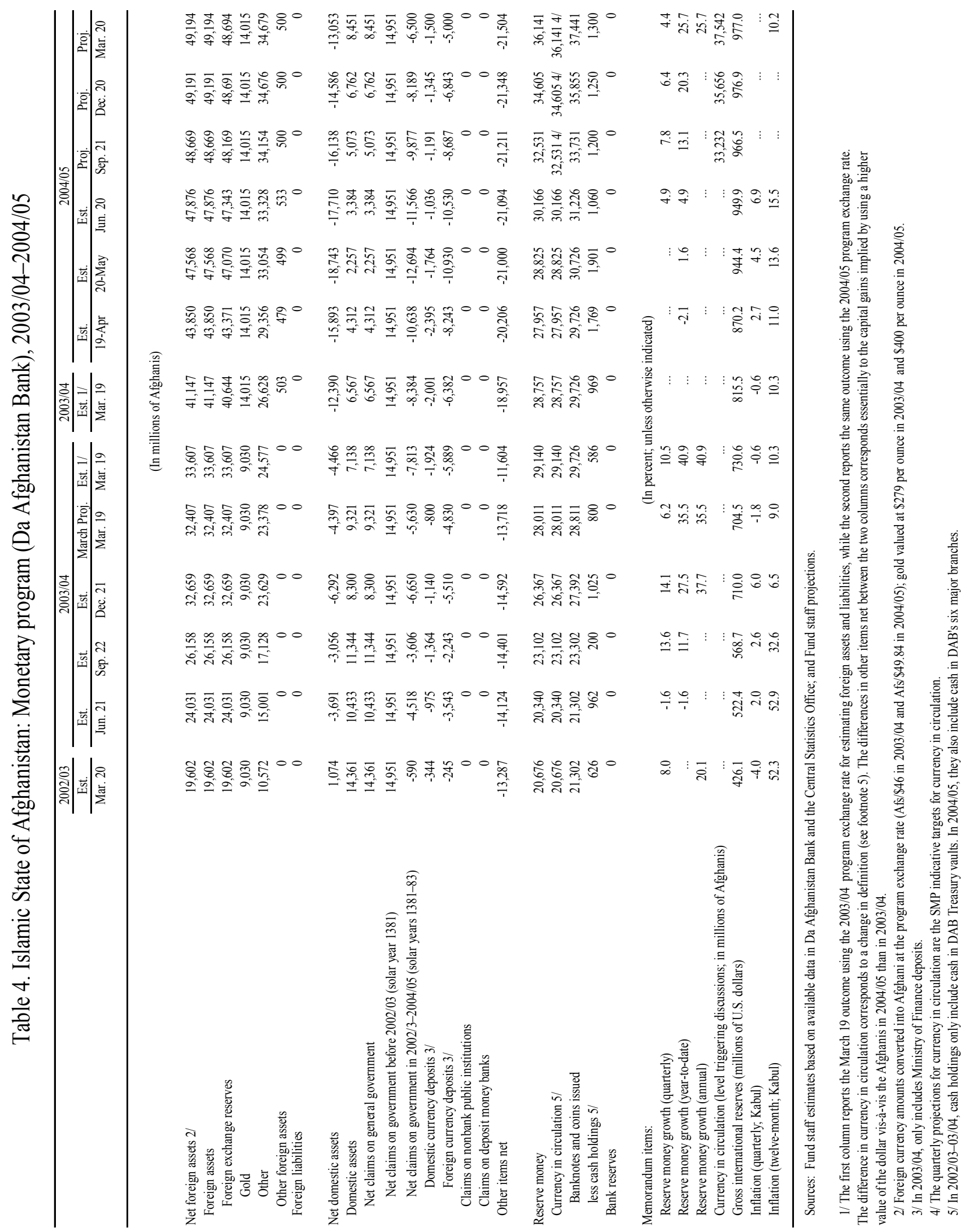


Table 5. Islamic State of Afghanistan: Balance of Payments, 2001/02-2007/08 1/

\begin{tabular}{|c|c|c|c|c|c|c|c|}
\hline & $2001 / 02$ & $\begin{array}{r}2002 / 03 \\
\text { Est. }\end{array}$ & $\begin{array}{r}2003 / 04 \\
\text { Est. }\end{array}$ & $\begin{array}{r}\text { 2004/05 } \\
\text { Proj. }\end{array}$ & $\begin{array}{r}\text { 2005/06 } \\
\text { Proj. }\end{array}$ & $\begin{array}{r}\text { 2006/07 } \\
\text { Proj. }\end{array}$ & $\begin{array}{r}\text { 2007/08 } \\
\text { Proj. }\end{array}$ \\
\hline & \multicolumn{7}{|c|}{ (In millions of U.S. dollars) } \\
\hline Trade balance & -936.1 & $-1,159.3$ & $-2,058.0$ & $-2,311.7$ & $-2,361.4$ & $-1,899.5$ & $-1,892.1$ \\
\hline Exports of goods 1/ & 708.9 & $1,248.3$ & $1,700.8$ & $1,822.5$ & $1,893.4$ & $1,860.9$ & $1,850.9$ \\
\hline Domestic exports & 85.2 & 276.8 & 445.8 & 642.3 & 875.9 & $1,041.4$ & $1,168.5$ \\
\hline Reexports & 623.7 & 971.5 & $1,255.0$ & $1,180.2$ & $1,017.4$ & 819.5 & 682.3 \\
\hline Imports of goods & $1,645.0$ & $2,407.6$ & $3,758.9$ & $4,134.1$ & $4,254.8$ & $3,760.4$ & $3,743.0$ \\
\hline Services & $\ldots$ & -145.1 & -516.7 & -528.5 & -518.6 & -338.2 & -272.6 \\
\hline Receipts & $\ldots$ & 50.8 & 124.9 & 131.6 & 135.3 & 108.4 & 101.3 \\
\hline Donor related & $\ldots$ & 45.9 & 113.5 & 117.1 & 115.6 & 73.8 & 59.0 \\
\hline Other & $\ldots$ & 4.9 & 11.3 & 14.6 & 19.7 & 34.6 & 42.4 \\
\hline Payments & $\ldots$ & 195.9 & 641.6 & 660.2 & 653.9 & 446.6 & 373.9 \\
\hline Donor related & $\ldots$ & 195.9 & 641.6 & 660.2 & 653.9 & 446.6 & 373.9 \\
\hline Wages of expatriates & $\ldots$ & 131.3 & 567.7 & 585.4 & 577.8 & 369.0 & 294.8 \\
\hline Other & $\ldots$ & 64.6 & 73.9 & 74.8 & 76.2 & 77.6 & 79.1 \\
\hline Income (net) & & -1.1 & -3.4 & 1.5 & 15.1 & 21.7 & 22.5 \\
\hline Receipts & & 0.0 & 4.9 & 11.2 & 27.2 & 35.4 & 37.7 \\
\hline Payments (Interest) 2/ & & 1.1 & 8.3 & 9.7 & 12.1 & 13.6 & 15.2 \\
\hline Current transfers & $\ldots$ & $1,221.7$ & $2,535.7$ & $2,747.6$ & $2,657.6$ & $1,997.6$ & $1,903.2$ \\
\hline Public & $\ldots$ & $1,170.1$ & $2,530.3$ & $2,747.6$ & $2,657.6$ & $1,997.6$ & $1,903.2$ \\
\hline Commodity food aid & 71.1 & 94.0 & 21.0 & 0.0 & 0.0 & 0.0 & 0.0 \\
\hline Other & $\ldots$ & $1,076.2$ & $2,509.3$ & $2,747.6$ & $2,657.6$ & $1,997.6$ & $1,903.2$ \\
\hline Private & $\ldots$ & 51.6 & 5.4 & 0.0 & 0.0 & 0.0 & 0.0 \\
\hline Other & $\ldots$ & 0.0 & 0.0 & 0.0 & 0.0 & 0.0 & 0.0 \\
\hline Current account balance & $\ldots$ & -83.8 & -42.4 & -91.1 & -207.3 & -218.4 & -239.0 \\
\hline (before grants) & $\cdots$ & $-1,305.5$ & $-2,578.2$ & $-2,838.7$ & $-2,864.9$ & $-2,216.0$ & $-2,142.2$ \\
\hline Capital financial account & $\ldots$ & 144.0 & 145.9 & 242.0 & 256.6 & 277.5 & 298.1 \\
\hline Public loans & $\cdots$ & 94.0 & 88.1 & 160.2 & 158.8 & 168.8 & 168.8 \\
\hline Disbursements & $\ldots$ & 100.2 & 94.3 & 166.4 & 165.0 & 175.0 & 175.0 \\
\hline Amortization paid 2/ & $\ldots$ & 6.2 & 6.2 & 6.2 & 6.2 & 6.2 & 6.2 \\
\hline Direct investment & $\ldots$ & 50.0 & 57.9 & 81.8 & 97.8 & 108.7 & 129.3 \\
\hline Other capital flows & & 0.0 & 0.0 & 0.0 & 0.0 & 0.0 & 0.0 \\
\hline Net errors and ommisions & $\ldots$ & 95.1 & 275.5 & 0.0 & 0.0 & 0.0 & 0.0 \\
\hline Overall balance & $\ldots$ & 155.3 & 379.0 & 150.9 & 49.3 & 59.1 & 59.0 \\
\hline Financing & $\ldots$ & -155.3 & -379.0 & -150.9 & -49.3 & -59.1 & -59.0 \\
\hline Change in net foreign assets of $\mathrm{DAB}$ & $\cdots$ & -101.0 & -389.4 & -161.5 & -60.0 & -70.0 & -70.0 \\
\hline Fund credit (net) & & 0.0 & 0.0 & 0.0 & 0.0 & 0.0 & 0.0 \\
\hline Purchases & & 0.0 & 0.0 & 0.0 & 0.0 & 0.0 & 0.0 \\
\hline Repurchases & & 0.0 & 0.0 & 0.0 & 0.0 & 0.0 & 0.0 \\
\hline Exceptional financing & & -54.3 & 10.4 & 10.6 & 10.7 & 10.9 & 11.0 \\
\hline Arrears & $\ldots$ & -54.3 & 10.4 & 10.6 & 10.7 & 10.9 & 11.0 \\
\hline Debt rescheduling & & 0.0 & 0.0 & 0.0 & 0.0 & 0.0 & 0.0 \\
\hline Debt forgiveness & & 0.0 & 0.0 & 0.0 & 0.0 & 0.0 & 0.0 \\
\hline Financing gap & & 0.0 & 0.0 & 0.0 & 0.0 & 0.0 & 0.0 \\
\hline \multicolumn{8}{|l|}{ Memorandum items: } \\
\hline \multicolumn{8}{|l|}{ Official foreign exchange reserves } \\
\hline In millions of U. S. dollars & & 426.1 & 815.5 & 977.0 & $1,037.0$ & $1,107.0$ & $1,177.0$ \\
\hline In months of prospective imports 3 / & & 1.6 & 2.7 & 3.0 & 3.7 & 3.9 & 4.0 \\
\hline \multicolumn{8}{|l|}{ Current account balance as share of GDP } \\
\hline Including grants & & -2.1 & -0.9 & -1.6 & -3.0 & -2.7 & -2.5 \\
\hline Excluding grants & & -32.2 & -56.2 & -48.9 & -40.8 & -27.1 & -22.5 \\
\hline GDP (millions of U. S. dollars) & & 4,048 & 4,585 & 5,802 & 7,016 & 8,178 & $9,530.0$ \\
\hline
\end{tabular}

Source: Fund staff estimates and projections.

1/ Excludes opium exports and, because information is unavailable, flows associated with U.S. Army and most ISAF activities.

2/ Debt service projections are based on recognized obligations, reconciled with creditors. Arrears shown here represent an estimate by Fund staff, on the basis of loans which have been verified with creditors, but are not being serviced.

3/ In months of prospective imports of goods and services, excluding imports for reexport. 


\section{Islamic State of Afghanistan: Relations with the Fund}

(As of August 31, 2004)

I. Membership Status: Joined July 14, 1955; Article XIV.

II. General Resources Account

Quota

Fund holdings of currency

Reserve position in Fund

Holdings Exchange Rate

III. SDR Department

Net cumulative allocation Holdings

\begin{tabular}{rr} 
SDR Million & \% Quota \\
\hline 161.90 & 100.00 \\
161.92 & 100.01 \\
0.00 & 0.00
\end{tabular}

$\frac{\text { SDR Million }}{26.70} \quad \frac{\% \text { Allocation }}{100.00}$

$0.07 \quad 0.26$

IV. Outstanding Purchases and Loans None

V. Financial Arrangements None

VI. Projected Obligations to Fund

(SDR Million; based on existing use of resources and present holdings of SDRs)

\begin{tabular}{|c|c|c|c|c|c|c|}
\hline & Overdue & & & thcon & & \\
\hline & August 31, 2004 & 2004 & $\underline{2005}$ & $\underline{2006}$ & 2007 & $\underline{2008}$ \\
\hline Principal & 0.00 & 0.00 & $\overline{0.00}$ & $\overline{0.00}$ & $\overline{0.00}$ & 0.00 \\
\hline Charges/Interest & $\underline{0.00}$ & $\underline{0.13}$ & $\underline{0.52}$ & $\underline{0.52}$ & $\underline{0.52}$ & $\underline{0.52}$ \\
\hline Total & 0.00 & 0.13 & $\overline{0.52}$ & $\overline{0.52}$ & $\overline{0.52}$ & 0.52 \\
\hline
\end{tabular}

\section{NONFINANCIAL RELATIONS}

\section{Exchange Arrangement}

Afghanistan is an Article XIV country. The authorities are implementing a liberal exchange system. Based on information currently available to the staff, no exchange restrictions and multiple currency practices are currently in place. The authorities intend to formalize the current liberal regime through the adoption of new laws and regulations, for which they have asked for technical assistance from the Fund. At least since end-2001, the Afghani has been floating, and more recently the authorities have been implementing a managed float with no predetermined path for the exchange rate. As of September 28, 2004, the average exchange rate on the Kabul money exchange market was Af 45.24 per $\$ 1$.

To conduct monetary policy, the authorities rely on foreign exchange auctions since May 2002. Auctions are open to all licensed money changers. To ensure transparency, DAB has progressively introduced measures, including public announcements of the auctions in 
advance in local media outlets, and clear instructions on how the autions are conducted. Over the years, DAB has also improved the mechanics of the auctions to ensure that settlements are made after successful bids. Auctions are linked to the overall monetary program and are held on a fairly regular basis at 1-2 week intervals.

\section{Article IV Consultation}

The last Article IV consultation with Afghanistan was discussed by the Executive Board on November 21, 2003. Consultations with Afghanistan are on the standard 12-month cycle.

\section{Technical Assistance, 2002-04}

\begin{tabular}{|c|c|c|}
\hline Department & Date & Purpose \\
\hline Interdepartmental & January $27-31,2002$ & Initial assessment of TA needs \\
\hline \multirow[t]{7}{*}{ FAD } & February $10-21,2002$ & Fiscal management \\
\hline & May 13-26, 2002 & Tax policy and administration \\
\hline & January 5-18, 2003 & Fiscal management \\
\hline & October 22-November 4, 2003 & Expenditure management \\
\hline & March 2004 until today & Resident Treasury Expert \\
\hline & March 22-April 3, 2004 & Tax policy and administration \\
\hline & April 18-May 2, 2004 & Customs administration \\
\hline \multirow[t]{6}{*}{ MFD } & February 27-March 7, 2002 & Financial sector reform \\
\hline & $\begin{array}{l}\text { May 19-June 2, July 10-27, } \\
2002\end{array}$ & Financial sector reform \\
\hline & December 11-16, 2002 & Financial sector legislation workshop \\
\hline & September 7-16, 2003 & $\begin{array}{l}\text { DAB restructuring program and } \\
\text { creation of a central bank short-term } \\
\text { debt instrument. }\end{array}$ \\
\hline & February 2-6, 2004 & Anti-money laundering legislation \\
\hline & March 21-30, 2004 & $\begin{array}{l}\text { DAB capital adequacy and balance } \\
\text { sheet structure }\end{array}$ \\
\hline \multirow[t]{4}{*}{ LEG } & February 27-March 7, 2002 & Financial sector legislation \\
\hline & December 11-16, 2002 & Financial sector legislation workshop \\
\hline & February 2-6, 2004 & Anti-money laundering legislation \\
\hline & March 3-21, 2004 & Fiscal revenue legislation \\
\hline \multirow[t]{9}{*}{ STA } & April 15-21, 2002 & Multisector statistics \\
\hline & November $18-30,2002$ & Consumer Price Index \\
\hline & January 26-February 8, 2003 & Government finance statistics \\
\hline & March 1-11, 2003 & Monetary and financial statistics \\
\hline & June 9-20, 2003 & Consumer Price Index \\
\hline & January 29-March 15, 2004 & Multisector statistics \\
\hline & April 19-May 3, 2004 & Balance of Payments Statistics \\
\hline & May 13-June 30, 2004 & Multisector statistics \\
\hline & May $17-29,2004$ & Consumer Price Index \\
\hline
\end{tabular}


A resident treasury expert for the Ministry of Finance, Mr. Platais, was appointed in March 2004.

Joint MFD and LEG technical assistance missions on anti-money laundering and foreign exchange law are scheduled for the second half of 2004.

A resident multisector statistical advisor, Mr. Soulatha, was stationed in Kabul on July 17,2002 . STA is currently providing technical assistance through a series of missions under a peripatetic multisector statistics assignment which began in January 2004. These missions were suspended in July 2004 due to the security situation. They may resume following the national elections based on a reassessment of the security situation.

A resident MFD expert was posted during July-October 2002 at DAB as an accounting adviser. In addition, from April 2002 to February 2003, several experts visited Kabul to provide advice on payment systems, restructuring of DAB, and bank supervision.

During 2004, with the financial support provided by the Sweden Technical Assistance SubAccount, the Fund has sponsored a number of training activities aimed at DAB officials and is now engaged in preparing a full-scale training program for DAB. A long-term advisor has been appointed, and will be based temporarily in Islamabad until security conditions permit his posting in Kabul. The training coordinator will be responsible for all practical matters related to the delivery of formal training to DAB staff in Kabul, as well as the coordination of training for DAB staff outside Afghanistan. Finally, Sweden has agreed to finance during the period December 2004 to December 2005 a monetary policy peripatetic advisor to assist DAB in developing the strategy and the instruments for the implementation of the next stage of monetary policy - setting and advising on options to replace the existing exchange rate auctions.

\section{Resident Representatives}

During the first half of 2002, the Fund's resident representative in Pakistan, Mr. Ghesquière, assisted in maintaining relations with the Afghan authorities. A resident representative, Mr. de Schaetzen, took up his post in Kabul on August 24, 2002. 


\section{Islamic State of Afghanistan: Relations with the World Bank}

1. A second Transitional Support Strategy (TSS) was presented to the World Bank Board of Executive Directors in March 2003. The TSS outlines a strategy for World Bank operations over the subsequent 18 months to 2 years until the establishment of a stable, representative government. The strategy focuses on four strategic areas: improving livelihoods, fiscal strategy, institutions and management, governance and public administration reform, and enabling private sector development.

2. In FY 2002, World Bank staff prepared and negotiated four projects to utilize IDA grant funds to a total of $\$ 100$ million. Following the clearance of Afghanistan's arrears to the World Bank and Fund, through donor contributions, the first IDA credit for \$108 million for the Emergency Transport Project was approved by the Board in March 2003. By the end of FY 2003 an additional three projects - Emergency Health Sector Rehabilitation (\$59.6 million), Emergency Public Administration II (\$8.4 million), and National Emergency Employment II (\$39.2 million) were approved bringing to \$215 million the total allocation for the year.

3. Five IDA credits/grants have been negotiated for FY 2004, for a total of \$293 million. These programs include the Emergency Communications Project ( $\$ 22$ million), the Emergency Customs Modernization and Trade Facilitation (\$31 million), the National Solidarity Program II ( $\$ 95$ million), the Emergency Irrigation Rehabilitation (\$40 million), and the Emergency Power Rehabilitation (\$105 million).

4. For FY 2005, four projects have been approved in July 2004, for a total of \$145 million: the first budget-support operation, Programmatic Support for Institution Building (\$80 million), the Kabul Urban Reconstruction Project (\$25 million), the Investment Guarantee Facility (\$5 million), together with MIGA, and the Education Quality Improvement Program (\$35 million). Four other projects are planned, for an additional commitment of \$140 million, including the Emergency Public Administration III, a supplemental financing for the Emergency Transport, the Programmatic Support for Institution Building II, and the Strengthening Higher Education project.

5. The World Bank also administers the Afghanistan Reconstruction Trust Fund (ARTF), which became effective in May 2002 and plays a critical role in funding the recurrent costs of government. In its first year of operation (SY 1381-March 21, 2002 to March 20, 2003) the ARTF mobilized \$185 million and disbursed \$65 million. Paid-in contributions for SY 1382 (March 21, 2003 to March 20, 2004) amounted to \$286 million, while disbursements reached \$254 million. Pledges for SY 1383 (March 21, 2004 to March 20, 2005) amount to $\$ 337$ million. ARTF is increasing its financing of investments and has the potential to support tighter donor coordination, simplified processes, and fast results. 
6. The World Bank is also actively engaged in advisory services to government and continues to respond quickly to a range of requests. In September 2004, the World Bank has released a country economic report "State Building, Sustaining Growth, and Reducing Poverty." Current analytical work includes work on the civil service reform, urban development and land management, education policy reform, labor market and pensions, a gender assessment and oil/gas infrastructure development, as well as broader regional trade work encompassing issues with Afghanistan's neighbors. The World Bank has also actively utilized Post Conflict Fund and continues to use the Japan Social Development Fund resources to provide on-the-ground support to the government and communities.

7. The World Bank's program is growing quickly and has a portfolio of 17 projects as of August 2004. Total commitments add up to $\$ 753$ million, of which 23 percent has been disbursed. The World Bank's office in Kabul is fully functional and growing rapidly to take on increasing demands. A country manager, as well as several other international staff, and a growing number of national staff are now in place. 
Kabul, September 6, 2004

\author{
Mr. Rodrigo de Rato y Figaredo \\ Managing Director \\ International Monetary Fund \\ Washington, D.C. 20431 \\ U.S.A.
}

Dear Mr. de Rato:

1. The government of Afghanistan is pleased with the progress made under the IMF staff-monitored program (SMP) agreed to in March 2004. Through our determined efforts, and with the support of your staff, we have met all of the quantitative indicators and structural benchmarks that were established for the first review of the program, except the benchmark on licensing of commercial banks, which was only met partially due to a technical delay. Along with our development partners, we view this program as an important catalyst for our ambitious reform and reconstruction agenda. We are already seeing tangible benefits of the program, and we have been able to maintain sound macroeconomic conditions while facilitating private sector growth. Clearly, however, much remains to be done, and our goal is to build on the progress already achieved.

2. At the time the program was adopted, we indicated that we would need to decide on structural benchmarks for end-December 2004 and end-March 2005 after completing the first review. Working together with the IMF mission that visited Kabul in July 2004, we reached understandings on a revised macroeconomic framework for 2004/05, on one additional structural benchmark for end-September 2004, and on a set of structural benchmarks for end-December 2004 and end-March 2005. The new benchmarks are consistent with the original March 24, 2004 Memorandum of Economic and Financial Policies (MEFP) that described our program for 2004/05.

3. The attached memorandum, prepared in consultation with Fund staff, updates the original MEFP to reflect recent developments and highlights some of the key achievements. We hope that the continued successful implementation of the SMP will lead to a successor Fund-supported program for 2005/06. 
4. The government believes that the policies and measures described in the March 2004 MEFP and in the attached update to the MEFP are sufficient to attain the 2004/05 program objectives, but we stand ready to take appropriate further measures. The government will continue to remain in close consultation with Fund staff, and will provide information that Fund staff requests to assess the implementation of the SMP, as updated.

5. In order to enhance transparency of our economic policies, we request that this letter, and the update to the MEFP, be published on the Fund's website.

Very truly yours,

$/ \mathrm{s} /$

Ashraf Ghani

Minister of Finance

Ministry of Finance
$/ \mathrm{s} /$

Anwar Ul-Haq Ahady

Governor

Da Afghanistan Bank

Attachments:

Update to the Memorandum of Economic and Financial Policies

Amendments to the Technical Memorandum of Understanding 


\section{Update to the Memorandum of Economic and Financial Policies}

\section{INTRODUCTION}

1. During the first quarter of 2004/05, the government of Afghanistan began implementing the staff-monitored program (SMP) with the International Monetary Fund (IMF), covering the period March 20, 2004-March 20, 2005. We are pleased to report that all prior actions, indicative quantitative targets, and structural benchmarks for end-June were observed, except the benchmark on licensing of commercial banks, which was only met partially due to a technical delay. In particular, we adopted measures to improve financial management, licensed several banks, implemented a customs policy reform, adopted a development budget, and created a technical committee to strengthen our institutional and administrative capacity to monitor macroeconomic developments and execute the SMP.

2. In meeting the targets and benchmarks under the program, we have demonstrated our continued strong commitment to macroeconomic stabilization and structural reform. We fully expect this performance to continue through the remaining months of the SMP.

Together with the IMF mission that visited Kabul during July 11-25, 2004, we have revised the macroeconomic framework for 2004/05 and for the medium term, established one additional structural benchmark for end-September 2004, and reached understandings on new structural benchmarks for end-December 2004 and end-March 2005.

3. This Memorandum of Economic and Financial Policies (MEFP) updates the MEFP dated March 24, 2004, which outlined our strategy for reform and described the government's economic program for 2004/05. By publishing this updated memorandum, the government reaffirms its commitment to keep the public informed about its policies and objectives, enhance transparency, and set the economy on an irreversible path for economic reform and growth.

\section{ReCENT ECONOMiC DeVElopments ANd PeRformance UNDER The SMP}

4. Real GDP is estimated to have grown by 16 percent in $2003 / 04$, compared with an initial estimate of 23 percent. This significant revision mainly reflects lower-thananticipated output in the agricultural sector attributable primarily to the lingering drought affecting some regions and to a lower outturn in the hydroelectric sector, which also was adversely affected by the drought.

5. Consumer prices increased by 6.9 percent during the first quarter of 2004/05, significantly more than during 2003/04, when quarterly price increases averaged 2.5 percent. This rise in consumer price inflation reflected primarily increases in rents, education fees, and other nontradables. While partly explained by seasonal factors (return of Afghanis living in Pakistan for the summer season; poppy crop season), and tax-related factors (introduction of the rental tax), this pick up in the Consumer Price Index (CPI) may also stem from higher spending by the donor community on nontraded goods. Over the last 12 months, the prices of rents, education, health, and transportation have increased substantially faster than the overall index. Excluding these four sectors, which represent 
12 percent of the overall index, consumer prices have increased by 11.3 percent over the last 12 months (compared to 15.5 percent for the overall index) and by 2.7 percent over the last three months.

6. Fiscal revenue for the first quarter of 2004/05 reached Af 2.6 billion, slightly exceeding the target level of Af 2.5 billion. ${ }^{5}$ Similar to the pattern observed in 2003/04, the government's operating expenditures were relatively slow during the first quarter of the year, reaching an estimated Af 4.8 billion, compared with an annual budgeted amount of Af 30.3 billion (10.5 percent of GDP). This was attributed to problems in communicating budget allotments to line ministries and the government units in the provinces (moustoufiats) along with procurement constraints and weak financial management capacity.

7. In June 2004, we adopted a 'core budget' that consolidates, for the first time, the operating budget with a significant share of development spending. Total spending for the core budget is projected at Af 69 billion (24 percent of GDP) for FY 2004/05, of which Af 38 billion constitutes planned spending on development projects that is channeled through the treasury system. The development projects included in the core budget are fully funded by the government or donors. All development projects, whether included in the core budget or outside it, are classified as National Programs (NPs) or National Priority Programs (NPPs). We expect that, in addition to the financing of the expenditures currently included in the core budget, grants and concessional loans of Af 15.2 billion will be available to the core budget this year. We will use them to both augment the NPPs and help finance existing donor projects that are currently outside the core budget and only partially funded. We expect to fully allocate these funds by September this year. The government estimates that spending undertaken directly by donors outside the core budget could reach Af 172 billion, although only Af 128 billion of donor grant commitments had been confirmed by the time the core budget was presented. The development of the core budget is an important step toward a comprehensive budget that incorporates all fiscal spending.

\section{During the first quarter of 2004/05, currency in circulation increased by} 5.4 percent (51.0 percent year-on-year), slightly less than envisaged under the program (6.3 percent). This increase in money supply resulted from the conversion of foreign currency into Afghanis by the Ministry of Finance (MoF) and by donors, which was only partly sterilized through foreign currency auctions. Along with the accumulation of foreign currency deposits by the government, this resulted in a significant increase in international reserves, to $\$ 950$ million at end-quarter (3.2 months of projected 2004/05 imports), well above the SMP floor.

\footnotetext{
${ }^{5}$ At the time of the review, the revenue information from a number of large provinces had not been fully reconciled with bank data from the central bank (Da Afghanistan Bank (DAB)).
} 
9. The appreciation of the Afghani points to increasing acceptance of the domestic currency. After depreciating during the last quarter of 2003/04, the Afghani has been appreciating steadily, gaining 8 percent vis-à-vis the U.S. dollar between end-March 2004 and end-July 2004. This appreciation, at a time of increasing inflation, appears to reflect a greater willingness by the population to use the Afghani as a medium of exchange and as a store of value. This trend appears to be attributable to the relative stability of the exchange rate since the introduction of the new currency, administrative measures aimed at promoting its use, such as the requirement that shopkeepers must price goods in Afghanis. Donors are increasingly making payments in Afghani instead of U.S. dollars and this appears to be widely accepted.

10. Further steps were taken toward the modernization of the central bank and the creation of a sound financial system. A preliminary assessment of Da Afghanistan Bank's (DAB) balance sheet was finalized, paving the way toward its restructuring. DAB's Supreme Council adopted a plan for introducing a short-term capital note, designed primarily to help establish a benchmark interest rate, and thereby facilitate development of a domestic credit market. New banking licenses were granted, raising to seven the number of new commercial banks operating in Afghanistan, all of them being financed by foreign investment. Two of the six state-owned banks were relicensed, and the liquidation of three others was initiated. A final decision regarding the Export Promotion Bank (EPB) had to be delayed for three months due to a decision by its shareholders to reject a restructuring involving merger with the three other state banks. Regular reporting to DAB supervision department was initiated, and a monetary survey, including the balance sheet of commercial banks, was developed.

11. Data for the external accounts are limited. However, based on revised estimates of trade data, the external current account balance (before grants) deteriorated in 2003/04 to a deficit of 56 percent of GDP, compared to a deficit of 32 percent in 2002/03. The deterioration resulted largely from a surge in imports associated with reconstruction and rising consumer demand. Donor inflows, predominantly in the form of grants, continued to finance the deficit, along with some private inflows in the form of foreign direct investment. Disbursements of external loans remained limited and on highly concessional terms. The large and positive errors and omissions in the balance of payments suggests that unrecorded inflows (perhaps from opium exports, unrecorded foreign investments and capital flows, or remittances) continue to be present.

\section{The Program FOR 2004/05}

\section{We recognize that recent movements in consumer price inflation, the} appreciation of the exchange rate and the downward revision of real GDP growth for 2003/04 pose new policy challenges. Further, continued insecurity in a number of regions and the reemergence of drought in some provinces, add to the challenges we are facing. Nevertheless, we remain confident in our ability to implement the measures contained in the SMP, and believe our track record over the last two years speaks to the government's capacity to operate under difficult conditions. At the same time, we are witnessing some 
favorable developments, including the continued delivery of substantial external assistance following the recent Berlin conference, growing confidence in the Afghani, and several key projects in the agricultural and manufacturing sectors coming on stream.

\section{Against this background, we have decided to update the macroeconomic}

framework for 2004/05. In light of the largely unavoidable increase in the prices of some nontraded goods in a context of large donor inflows and limited supply response, the revised program aims at containing inflation at 10 percent (compared to 5 percent in the original program). At the same time, recognizing that some of the unexpected shortfall in real output in 2003/04 was temporary, we have slightly raised the real economic growth target from 15 percent to 16 percent. We anticipate that the agriculture sector will reap the benefits of the full production cycle and better land moisture this year, and that construction will provide the additional impetus for economic growth. These outcomes, together with a stable exchange rate, are expected to translate into a rise of per capita income to $\$ 246$, compared with $\$ 199$ in 2003/04.

\section{We estimate that the overall investment rate remains high, at 43 percent of GDP} in 2004/05, largely because of continued donor assistance while the opening of several commercial banks should boost private investment. We expect our current account deficit to narrow by 7 percentage points of GDP to 49 percent of GDP, as exports continue to recover and the surge in import demand levels off, and our gross official reserves to rise by about $\$ 162$ million to a level equivalent to over three months of prospective imports of goods and nonfactor services.

15. Pursuing sound fiscal and monetary policies will be critical to achieve the program's quantitative targets (Table 1). To improve the prospects for sustained economic growth, we will pursue our structural reforms (Table 2).

\section{A. Fiscal Policy}

16. The successful execution of our fiscal policy will depend on our ability to rebuild domestic tax collection. While first quarter revenue represents a significant increase (about 23 percent) over the same period last year, we recognize that the budgetary target for domestic revenue of Af 15.2 billion $^{6}$ for 2004/05 is ambitious and that compliance rates need to be increased (and illegitimate charges reduced), particularly at border posts where the majority of revenues are generated.

\section{We remain committed to implementing our five-year reform plans for both} customs and domestic tax administration. We have implemented a number of customs reforms so far this year, including (i) the introduction of the Afghan Harmonized System Tariff that reduced the number of rates to 6 from 25, classified goods according to international standards and uses the official exchange rate as published by DAB for valuation purpose; (ii) the introduction of new procedures to control and monitor exemptions; (iii) an

\footnotetext{
6 The annual revenue target (floor) for the SMP is Af 12.784 billion (\$256 million).
} 
increase in the number of licensed customs brokers; and (iv) the gradual establishment of regional customs valuation units in the major provincial centers. With regard to the reform of domestic tax administration, we have (i) adopted a tax reform package; ${ }^{7}$ (ii) created a Large Taxpayer Office (we expect to appoint a head shortly); (iii) accelerated the nationwide roll out of the Taxpayer Identification Number (TIN) to the major provincial centers; and (iv) consolidated tax legislation to clarify the status of tax and customs legislation (this should be officially published shortly). In addition, we remain committed to enacting the new Customs Code this year and to ending tax concessions and tax holidays, which further undermine the tax base.

18. We expect expenditure to pick up significantly during the remainder of the year, particularly as late salary and wage payment are cleared and ongoing payments normalized, and to be in line with budgetary projections over 2004/05. The late payment of operating expenditures was also observed at the start of the previous year and is mainly attributed to weaknesses in the public expenditure management systems, including confusion over budget allotments, employment registers, and procurement constraints. The government will implement a more modern verified payroll system over the next few years, so as to improve payments, and is currently conducting a review of outstanding salary and wage payments from 2003/04 to verify the integrity of any claims before they are discharged. At the same time, we will continue to improve public expenditure management, particularly through the strict adherence to government procedures for verifying spending on operations and maintenance. Enforcing appropriate expenditure controls will enhance accountability and is part of a package of measures aimed at reducing existing payment problems and improving fiduciary standards. ${ }^{9}$

\section{We will continue to upgrade our public expenditure management systems.}

During the first quarter of the year, we have made progress in consolidating all line ministry accounts into the Treasury Single Account (TSA) and regularly transferring provincial moustoufiat balances into the TSA. This should enhance our ability to monitor and control revenue. The consolidation of accounts into the TSA and the planned improvements in the automation of the payments system, including electronic funds transfers through the DAB, should also enable the government to develop more modern, secure, and direct methods of payment for both salaries and goods and services that will greatly improve the efficiency of government operations.

\footnotetext{
7 This includes a wage withholding tax, a fixed tax on selected services, a reduction in the corporate tax rate to 20 percent, and a rent tax.

${ }^{8}$ This should also include a small amount of salary arrears outstanding from 2003/04.

${ }^{9}$ These measures include additional training for line ministries and moustoufiats in financial and procurement procedures, as well as new checks and balances and business processes with the MoF. In addition, donor financed Counterpart Chief Financial Officers (CCFOs) have been placed in the main line ministries to support and help to build local financial management capacity.
} 


\section{B. Monetary and Exchange Rate Policy}

20. DAB will maintain the current stance on monetary policy, with a view to maintaining low inflation, while guarding against currency instability. To that purpose, the central bank will be guided by the flexible monetary program developed with Fund staff in March, which will allow us to accommodate, up to a certain level ( 5 percent above the program target), perceived shifts in monetary demand. In view of the poor quality of consumer price statistics, particular attention will be paid to exchange rate developments. While keeping a close watch on price and exchange rate developments, should this flexibility turn out to be insufficient, we will consult with Fund staff on possible changes to the monetary targets under the SMP. Consistent with the unchanged approach to the target for currency in circulation, and given that a substantial portion of the buildup in international reserves stemmed from accumulation of government deposits, the indicative target for gross international reserves of the DAB will remain unchanged. We will, however, consult with Fund staff on this issue at the time of the second review.

21. We will actively pursue further measures deemed essential to reform the financial system. DAB's balance sheet will be restructured, including the transfer of DAB's commercial holdings to the MoF. Those commercial activities of DAB that are inconsistent with the functions of a central bank will be transferred to other entities in accordance with a memorandum of understanding between the MoF and the DAB. To minimize any potential further capital loss, this transfer will be bound to the transfer of monetary gold and silver from the palace vaults to DAB and forgiveness of DAB claims on the government. In addition, an auction process will be introduced for the short-term capital note. Finally, a decision will be taken regarding the relicensing application of the EPB.

\section{External Policy and Debt Management}

22. We remain committed to prudent management of external debt. Regarding the stock of debt, we have made progress in identifying debts undertaken by previous administrations, and reconciling these amounts with external creditors. More remains to be done in this area, however, as there are still a number of outstanding claims which have yet to be verified. Toward this end, we will complete by end-March 2005 a full and detailed inventory of external loans, verified with bilateral creditors. In this context, we will also continue to seek generous debt relief from bilateral creditors, which we see as essential to fiscal sustainability over the medium and long term. With regard to the flow of new loans, and as specified under the SMP, external loans contracted by the government of Afghanistan thus far in 2004/05 have been on highly concessional terms, and disbursements have been limited. To ensure that this prudent strategy remains a central pillar of Afghanistan's reconstruction and stabilization, we will make significant progress toward designing a comprehensive external debt management strategy.

\section{Structural Reforms}

23. There are key structural reforms that need to be implemented to achieve sustainable growth. We recognize that the agenda of structural benchmarks is extensive. However, the length and breadth of this agenda reflects both the government's desire to make 
real and effective reforms, and to demonstrate our commitment to establishing a track record, facilitating economic growth, and building much needed administrative capacity. Foremost, among these benchmarks are measures to address weaknesses in the regulatory environment and an inefficient public sector.

24. We have established a timetable for the closure or corporatization of the state-owned enterprises (SOE), and have completed an initial audit of their operations and assets. By end-December 2004, we will complete the assessment of their financial position and adopt a list of SOEs that will specify those slated for liquidation, privatization, or those to be maintained in the government's portfolio. Recognizing that the welfare of the employees of these firms is a crucial issue, we will also adopt an overall economic restructuring plan, which will guide the government's action in this area, for the future including efforts to retrain or reassign workers displaced by the rationalization of the state enterprise sector. Although not yet fully assessed, the fiscal cost associated with this overall exercise is expected to be small.

25. A critical element of our structural program is aimed at increasing private sector investment. Toward this end, we will prepare an action plan by end-September 2004 to address critical deficiencies in the investment climate, including revisions to the commercial code, property rights, and bankruptcy legislation.

\section{E. Program Monitoring}

26. In addition to the quarterly quantitative indicators for end-September 2004, end-December 2004, and end-March 2005 defined in the MEFP dated March 24, 2004, we have reached understandings with Fund staff on one additional structural benchmark for end-September 2004, and a set of structural benchmarks for end-December 2004 and end-March 2005. The structural benchmarks are detailed in Table 2.

27. Since it was created in early April, the Inter-Ministerial Technical Committee (TC), has been instrumental in effectively monitoring the implementation of the SMP and in providing core data to the Fund. Although the role and the specific missions of the TC were an entirely new concept, we made a lot of progress in getting this new institutional unit to work, meet regularly, and provide a forum for discussions and exchanges among staff from $\mathrm{DAB}$, the MoF, and the Central Statistic Office, the key government agencies currently involved in the SMP. In the months to come, the TC will focus its efforts on the timely execution of the SMP, intensifying the dialogue between government agencies, and setting the standards for better economic management.

28. The second review of the program is scheduled to take place on or after October 15 based on performance as of September 20, 2004. At the time of that review, those quantitative indicators and structural benchmarks for end-December 2004 and end-March 2005 may be revised in light of developments. 


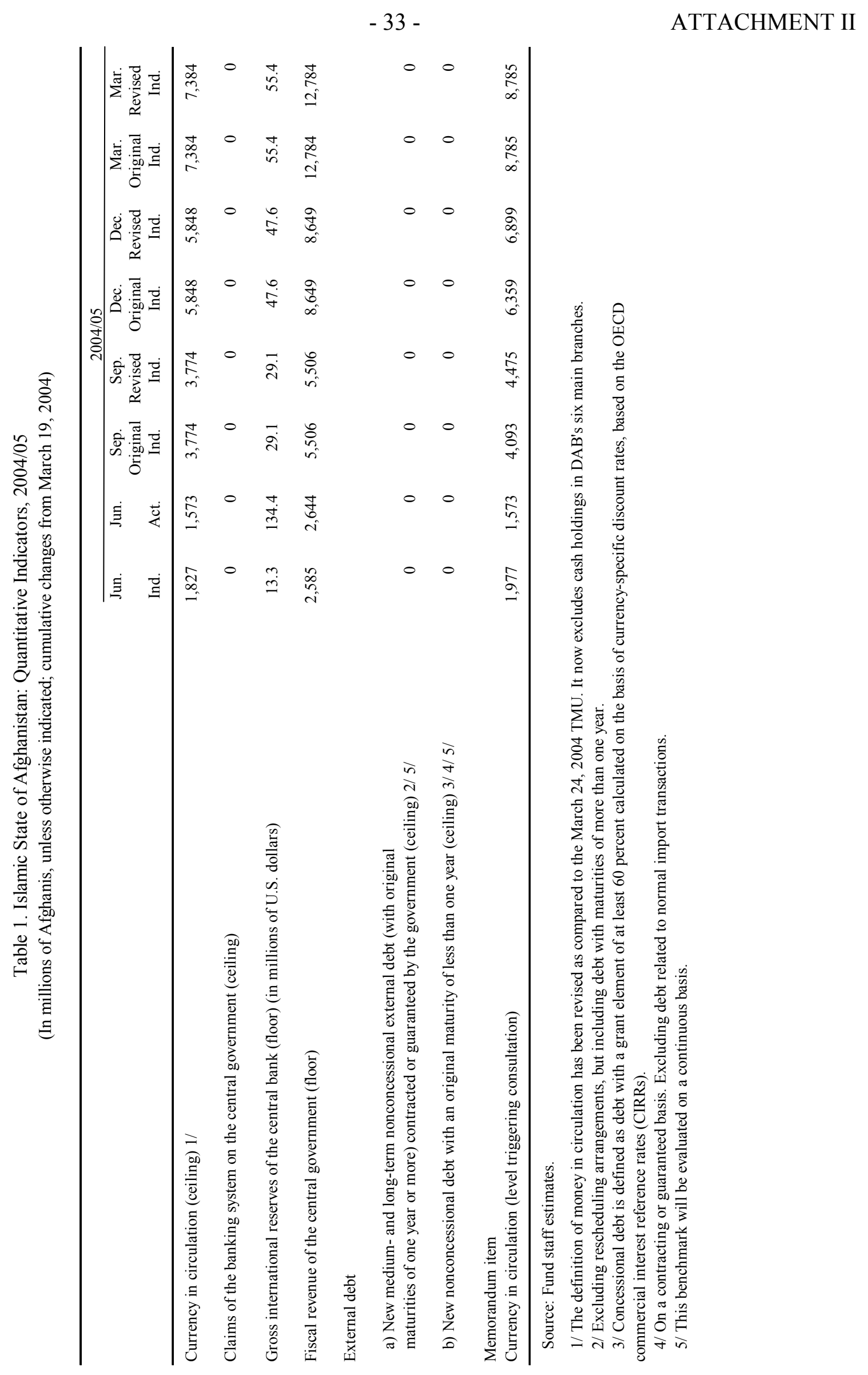




\section{Table 2. Islamic State of Afghanistan: Prior Actions and Structural Benchmarks Under the Staff-Monitored Program}

\section{Policy Actions}

Target Date

\section{Status}

\section{Prior Actions for Management Approval of the SMP}

Adopt the 2004/05 operating budget (by the Cabinet).

Establish procedures and a timetable for regular sweeping provincial balances into TSA at DAB headquarters and a plan to transfer all 2002/03 year-end balances in the provincial accounts and ministerial accounts to the treasury account at DAB.

Initiate the closure and resolution process for all banks that have not applied for licenses.

Set up an TC to coordinate the implementation of the SMP.

Sign a presidential decree enacting the tax policy package (see paragraph 11 of MEFP).

Adopt a ministerial order to implement the customs policy package (see paragraph 11 of MEFP).

Adopt a Cabinet resolution to draft legislation that eliminates tax exemptions and concessions except those contained in revenue legislation.

\section{Structural Benchmarks}

Consolidate all line ministry accounts into TSA.

Transfer regularly provincial moustoufiat balances into TSA at DAB headquarters, from at least 70 percent of provinces.

Adopt the 2004/05 development budget (by the Cabinet).

Establish a timetable for (a) a verified payroll of government employees; (b) a wage decompression compatible with medium-term fiscal sustainability; and (c) the closure or corporatization of public enterprises.

Transfer all 2002/03 year-end balances in the provincial accounts and ministerial accounts to the treasury account at DAB.
Implemented on March 18, 2004

Implemented on March 13, 2004

Implemented by DAB on March 16, 2004

Implemented on March 15, 2004

Implemented on March 18, 2004

Implemented on March 18, 2004

Implemented on March 18, 2004
End-June $2004 \quad$ Implemented

End-June $2004 \quad$ Implemented

End-June $2004 \quad$ Implemented 


\section{Table 2. Islamic State of Afghanistan: Prior Actions and Structural Benchmarks Under the Staff-Monitored Program (continued)}

\section{Policy Actions}

End-June 2004

End-June 2004

End-June 2004

Complete (by DAB) the relicensing operation of the commercial banks and begin the resolution proceedings for those whose licenses applications have been rejected.

Develop consolidated fiscal accounts including provinces and operating and development budgets (see paragraph 14 of the TMU).

Adopt a presidential decree enacting amendments to the tax and customs laws to preclude the use of tax exemptions or concessions, except those contained in revenue legislation and the existing statutory exemptions, grandfathered until March 20, 2005 (see paragraph 14 of the TMU).

Issue (a) presidential decree enacting Anti-Money Laundering/Combating Financial Terrorism (AML/CFT) legislation; and (b) a decision by the Supreme Council of DAB for a modern payment system.

Extend the consumer price index survey to main cities beyond Kabul.

Adopt (by the Cabinet) the 2003/04 final accounts (operating budget).

Transfer regularly within 30 days all provincial moustoufiat balances into TSA at DAB headquarters.

Complete the relicensing operation of, or begin the resolution proceeding for EPB of Afghanistan.

Complete an assessment of the financial position of the SOE. Adopt (by Cabinet) (a) the list classifying SOEs according to proposed economic restructuring method; and (b) the Economic Restructuring Plan.

Consolidate all recent revenue measures into the existing revenue code and publish as a single document.

\section{Target Date Status}

End-June 2004

End-June 2004

End-September 2004

End-September 2004

End-September 2004

End-September 2004

End-September 2004

End-December 2004
Implemented

Implemented

Largely implemented 1/

Implemented

Adopted

Under way

Under way

Under way

Under way

Under way

End-December 2004 


\section{Table 2. Islamic State of Afghanistan: Prior Actions and Structural Benchmarks Under the Staff-Monitored Program (continued)}

\section{Policy Actions}

\section{Target Date}

Status
Publish in the official gazette the central bank and commercial banks laws.

Introduce the auction process for a short-term $\mathrm{DAB}$ capital note.

Initiate an external audit of the DAB based on internationally recognized accounting standards.

Improve government payments by initiating (a) direct electronic payments to vendor bank accounts; and (b) a pilot for direct salary deposits to bank accounts for the employees of three ministries.

Adopt (by the Cabinet) and publish in the official gazette the financial management law.

Adopt new chart of accounts compatible with IMF GFS 2001 (cash basis) requirements for classifying revenue and expenditure transactions.

Transfer to other entities all DAB commercial activities that are inconsistent with the central bank and commercial banking laws.

Prepare (by MoF) monthly cash flow projections to improve cash management and for coordination with $\mathrm{DAB}$.

Complete the survey of external debt, including reconciliation with creditors.

Transfer of DAB's commercial holdings to the MoF, forgive pre-1381 claims on government, and transfer marketable gold and silver in the palace vaults to the DAB.

Implement a program to monitor and record duty exempt imports.

Adopt the consolidated budget for FY 2005/06 according to the structure of the new chart of accounts before the start of the fiscal year.

Approve (by the Cabinet) the Customs Code.
End-December 2004

End-December 2004

End-December 2004

End-December 2004

End-December 2004

End-December 2004

End-December 2004

End-December 2004

End-March 2005

End-March 2005

End-March 2005

End-March 2005

End-March 2005 
Table 2. Islamic State of Afghanistan: Prior Actions and Structural Benchmarks Under the Staff-Monitored Program (concluded)

\begin{tabular}{|c|c|c|}
\hline Policy Actions & Target Date & Status \\
\hline $\begin{array}{l}\text { Implement verified payroll plan by: (a) establishing through } \\
\text { decree or regulation that provide legal basis for a single } \\
\text { general employee database; and (b) ensuring that budget } \\
\text { allotments and authorized staff positions are entered into } \\
\text { AFMIS for all line ministries and their subordinated units in } \\
\text { the center and provinces before the start of the fiscal year. }\end{array}$ & End-March 2005 & \\
\hline Publish (by the MoF) on a quarterly basis fiscal data. & End-March 2005 & \\
\hline $\begin{array}{l}\text { Publication of an official estimate of the annual revenue } \\
\text { forgone as a result of tax holidays, exemptions or } \\
\text { concessions and a time-bound plan, approved by the MoF, } \\
\text { to address all existing tax exemptions or concessions. }\end{array}$ & End-March 2005 & \\
\hline
\end{tabular}

1/ Due to shareholder opposition to its merger with three other state-owned commercial banks, the EPB of Afghanistan had to resubmit an application for relicensing. 
INTERNATIONAL MONETARY FUND

ISLAMIC STATE OF AFGHANISTAN

\section{Amendments to the Technical Memorandum of Understanding}

1. Paragraph 5 will be replaced with: "Currency in circulation is defined as total currency (new Afghani) issued by DAB. It excludes currency held in the presidential palace vault, in the DAB main vault, and in the vaults of DAB's six main branches, but includes currency in the other branches'vaults."

2. The following sentence will be inserted at the end of the second bullet point of paragraph 14: "For each individual branch, the transferred amount will have to be credited to the TSA within 30 days of the end of each solar month."

3. The following bullet point will be inserted at the end of paragraph 14:

- $\quad$ Publication (by the MoF) of fiscal data on a quarterly basis. The data should be at least quarterly, but whenever possible, should include monthly revenue and expenditures (center and by individual province) covered under the core budget, as well as financing. The structure of the revenue and expenditure data should be on the same classification as the approved budget. The data should also compare outturns against the budget. As information on the external budget depends on cooperation from the donors, the government should make a "best effort" to compile the data, and make ongoing revisions. Published data should also include principal and interest payments on external government and government-guaranteed debt, and disbursement of external loans. Publication of this information can be in either electronic or paper format.

4. The second bullet point of paragraph 15 will be replaced by:

- Monetary statistics, including exchange rate data (daily), government accounts with the DAB and currency in circulation (monthly) from March 20, 2004. From

September 21, 2004, monetary statistics will also include a monetary survey (monthly), including balance sheets of DAB and a balance sheet of the commercial banks. This should be reported no longer than three weeks after the end of the month. 